\title{
Assessment of the ultra-trace mercury levels in selected desert plants
}

\author{
A. H. Bu-Olayan • B. V. Thomas
}

Received: 5 March 2012/Revised: 12 February 2013/ Accepted: 1 May 2013/Published online: 23 May 2013

(C) Islamic Azad University (IAU) 2013

\begin{abstract}
Conventional methods that assessed the mercury $(\mathrm{Hg})$ levels were not only an outcome of atmospheric pollution, but also the possibility of $\mathrm{Hg}$ contamination from the sample collection to laboratory analyses. Our studies used the direct mercury analyzer that measured $\mathrm{Hg}$ rapidly and precisely at ultra-trace concentrations with detection limit of $0.0015 \mathrm{ng} \mathrm{g}^{-1}$ on six favored desert plants and their surrounding soil in Kuwait. Analysis revealed elevated $\mathrm{Hg}$ concentrations in Tamarix chinensis Lour., and Salsola imbricate Forssk., among the chosen desert plants, especially during summer than in winter, thus labeling the qualities of a bio-indicator to $\mathrm{Hg}$ pollution. The overall parts-wise analysis on the six selected plants showed the elevated mean $\mathrm{Hg}$ concentrations in the leaves $\left(0.89 \mathrm{ng} \mathrm{g}^{-1}\right)$ followed by root $\left(0.51 \mathrm{ng} \mathrm{g}^{-1}\right)$ and stem $\left(0.39 \mathrm{ng} \mathrm{g}^{-1}\right)$ in the desert plants. Reasons attribute to the capability of these plant parts to absorb, accumulate, and assimilate $\mathrm{Hg}$ at varying concentrations. The overall mean $\mathrm{Hg}$ concentration was high in soil $\left(2.24 \mathrm{ng} \mathrm{g}^{-1}\right)$ in comparison with the mean $\mathrm{Hg}$ concentrations in the desert plants $\left(0.60 \mathrm{ng} \mathrm{g}^{-1}\right)$ irrespective of the two seasons. Translocation and bioaccumulation factors indicated low uptake of $\mathrm{Hg}$ translocation in the plant parts from the soil. Furthermore, the mean $\mathrm{Hg}$ concentration was found high in samples collected from Governorates (GIII) in comparison with the samples collected from other Governorates indicating the effect of pollution from various sources. The present study characterizes the selected plants as bio-indicators and also validates the impact of regional and
\end{abstract}

A. H. Bu-Olayan · B. V. Thomas $(\bowtie)$

Department of Chemistry, Kuwait University,

POB 5969, 13060 Kuwait City, Kuwait

e-mail: drbivin.thomas@ku.edu.kw seasonal variations to $\mathrm{Hg}$ pollution at ultra-trace levels in the arid ecosystem.

Keywords Bio-indicators · Flora $\cdot$ Soil $\cdot$ Metal pollution $\cdot$ Translocation

\section{Introduction}

The source of mercury $(\mathrm{Hg})$ in nature includes earthquakes, dust deposition, soil erosion, and volatilizations from the ocean. Rocks, sediments, water, and soils contain low levels of mercury. In the natural environment, scientists found high mercury levels in some minerals on earth and springs (USGS 2009). Metallic-Hg evaporates slowly to air exposures. The geo-accumulation index and enrichment factor indicated the dust-originated mercury from anthropogenic sources ( $\mathrm{Lu}$ et al. 2009). Particulate deposition on many edible vegetables and desert plants in excess produced physiological, pathological damage, and reduced yield (Freer-Smith et al. 2004; USEPA 2009; Ling et al. 2010; Morales et al. 2011; Suruchi and Khanna 2011).

Bio-monitors are very effective for tracing maps of metal contamination in the urban arid environment (Baker and Brooks 1989). Leaves are efficient accumulators of air particulates (Ma et al. 2001; Chung et al. 2005; Takashi et al. 2005; Morales et al. 2011). Freer-Smith et al. (2004) reported foliar contamination was severe at roadsides and similar pollution with particulate matter occurs in urban and suburban cities of various countries. Many shrubs and trees of drought and heavy metals tolerance that grew in semi-arid and arid regions revealed deposition of more particulates than other plants and found suitable for biomonitoring and phyto-remediation studies (Al-Farraj and 
Al-Wabel 2007; Prabha and Li 2007; Zhuang et al. 2007; Kadukova et al. 2008). Freer-Smith et al. (2004) observed two probable ways of damage in plants due to $\mathrm{Hg}$ uptake. They are elemental or gaseous $\mathrm{Hg}$ that is directly toxic, damaging sensitive cell membranes or they act as metabolic regulators or plant hormones and disrupt normal patterns of growth and development. Eboh and Thomas (2005), Onweremadu et al. (2007), Rafat et al. (2009), Keane et al. (2001), Converse et al. (2010) showed metal contents with quantitative measures of soil, air, and wastewater contamination at sites where plants grew. This assessed the plant tissue growth to that of the environmental metal content. Rafia et al. (2006), Katnoria et al. (2008) showed the effect of mercury in the experimental set-up as well as from soil to the growth inhibition in various plants.

The state of Kuwait recorded around 400 species of desert plants apportioned in six Governorate areas. Among these, 15-20 species were commonly spread over six Governorate areas of Kuwait (Greenwell 2008). Over the recent years, many desert plants in Kuwait were found at the verge of extinction. Reasons attribute to the rapid industrialization, exploitation by cattle, partial, or complete trampling due to construction and camping activities, impact of oil pollution through living medium, and rooting out plants for food and fuel (KUNA 2010), besides the increasing inorganic pollutants in the living media due to anthropogenic sources and dust storm. Kuwait experiences northwest and southeast wind direction during most part of the year. The wind speed is high during summer (12-14 $\mathrm{mph}$ ) than during winter $(9-10 \mathrm{mph})$ during normal weather (Windfinder 2011). At times, the wind speed has been reported to reach $30-35 \mathrm{mph}$ causing dust storms (Arab Times 2011). High wind speed causing raising dust carries organic and inorganic pollutants, especially during summer. One among the pollutants of recent interest is the uptake of mercury $(\mathrm{Hg})$ in the desert plant parts (leaves, stem, and root) through air and soil. These plants were the main source of food for the grazing cattle and accumulation of $\mathrm{Hg}$ in these cattle posed risk to humans. The source of $\mathrm{Hg}$ concentrations accumulated in the various parts of desert plants was suspected as a result of wind action (especially when the prevailing wind was from the northwest with a wind speed ranging between 1.5 and $2.5 \mathrm{~ms}^{-1}$ that resulted in the $\mathrm{Hg}$ increase between 1 and $<8 \mathrm{ng} \mathrm{m}^{-3}$ ), fugitive dust deposition, the possibilities of absorbing residual $\mathrm{Hg}$ in the un-reclamation soil leached from few chlor-alkali plants, partial translocation and bioaccumulation process, besides evaporation of soil-bound mercury during warm periods (Baker and Brooks 1989; Ma et al. 2001; Liu et al. 2002; Charron and Harrison 2003; Nahida et al. 2005; Takashi et al. 2005; Al-Awadhi et al. 2008). We conducted research on air pollution during the years
2009-2011 considering the global scenario on $\mathrm{Hg}$ pollution, frequent dust storms, and rapid urbanization in Kuwait in addition to the $\mathrm{Hg}$ concentration determination at ultra-trace levels in desert plants with unparalleled precision. Our investigations determined: (a) the mercury ( $\mathrm{Hg}$ ) concentrations in desert plants and soil using direct mercury analyzer (DMA-80: compliant to EPA 7473 method) with lowest possible detection limit of $0.015 \mathrm{ng} \mathrm{g}^{-1} \mathrm{Hg}$ in comparison with conventional methods (EPA, 245.1, 7471A) and analyzers (Hydra-IIc, Ohio Lumex) with higher detection limits $\geq 0.5 \mathrm{ng} \mathrm{g}^{-1}$ (Dufault et al. 2009; Kolesnikov et al. 2010), (b) the distribution and the effect of $\mathrm{Hg}$ levels in plants from the six Governorates of Kuwait during summer (April-September, 2009-2011) and winter seasons (October-March, 2009-2011), (c) to label selected desert plants as bio-indicators or accumulators to $\mathrm{Hg}$ pollution using translocation (TF) and bioaccumulation factors $(B F)$, and (d) an overview on the impact of environmental variables to $\mathrm{Hg}$ distribution.

\section{Materials and methods}

\section{Sampling sites}

Among the various kinds of desert plants in Kuwait, we chose commonly distributed six desert plants that were suspected for $\mathrm{Hg}$ accumulation through air and soil in four areas each, from six Kuwait Governorates (GI-GVI) (Fig. 1). Each Governorate in Kuwait showed similar geographical distribution of these plants but varied with the anthropogenic sources. The features of Kuwait Governorate areas $\left(17,820 \mathrm{~km}^{2}\right.$ ) are as follows: (1) GI (Jahra: $29^{\circ} 20^{\prime} 13.2^{\prime \prime} \mathrm{N}, 47^{\circ} 39^{\prime} 28.8^{\prime \prime} \mathrm{E}$ ) situated at the North of Kuwait mainly with desert and industrial, and sparingly populated residential areas (thermal, power, desalination, and water treatment plants are cited in this area), (2) GII (Al-Asimah/Kuwait City $29^{\circ} 21^{\prime} 57.6^{\prime \prime} \mathrm{N}, 47^{\circ} 58^{\prime} 40.8^{\prime \prime} \mathrm{E}$ ) is the central Kuwait zone with industrial, residential areas and significant for its business centers, (3) GIII (Hawalli $29^{\circ} 19^{\prime} 58.8^{\prime \prime} \mathrm{N}, 48^{\circ} 01^{\prime} 44.4^{\prime \prime} \mathrm{E}$ ) is a commercial center with moderately populated residential areas, (4) GIV (Farwaniya $29^{\circ} 16^{\prime} 37.2^{\prime \prime} \mathrm{N}, 47^{\circ} 57^{\prime} 32.4^{\prime \prime} \mathrm{E}$ ) is a densely populated residential area, (5) GV (Mubarak Al-Kabeer: $29^{\circ} 15^{\prime} 25.2^{\prime \prime} \mathrm{N}$, $48^{\circ} 03^{\prime} 25.2^{\prime \prime} \mathrm{E}$ ) has moderately populated residential areas and also noted for many recreational centers, and (6) GVI (Ahmedi $29^{\circ} 4^{\prime} 37.2^{\prime \prime} \mathrm{N}, 4^{\circ} 05^{\prime} 2.4^{\prime \prime} \mathrm{E}$ ) is the Kuwait's southern region with oil fields and oil wells (Fig. 1).

Meteorological data

Kestrel-4200 (Nielsen-Kellerman, USA) determined the mean 24-h meteorological data for the summer (April- 
Fig. 1 Sampling sites of Kuwait Governorates

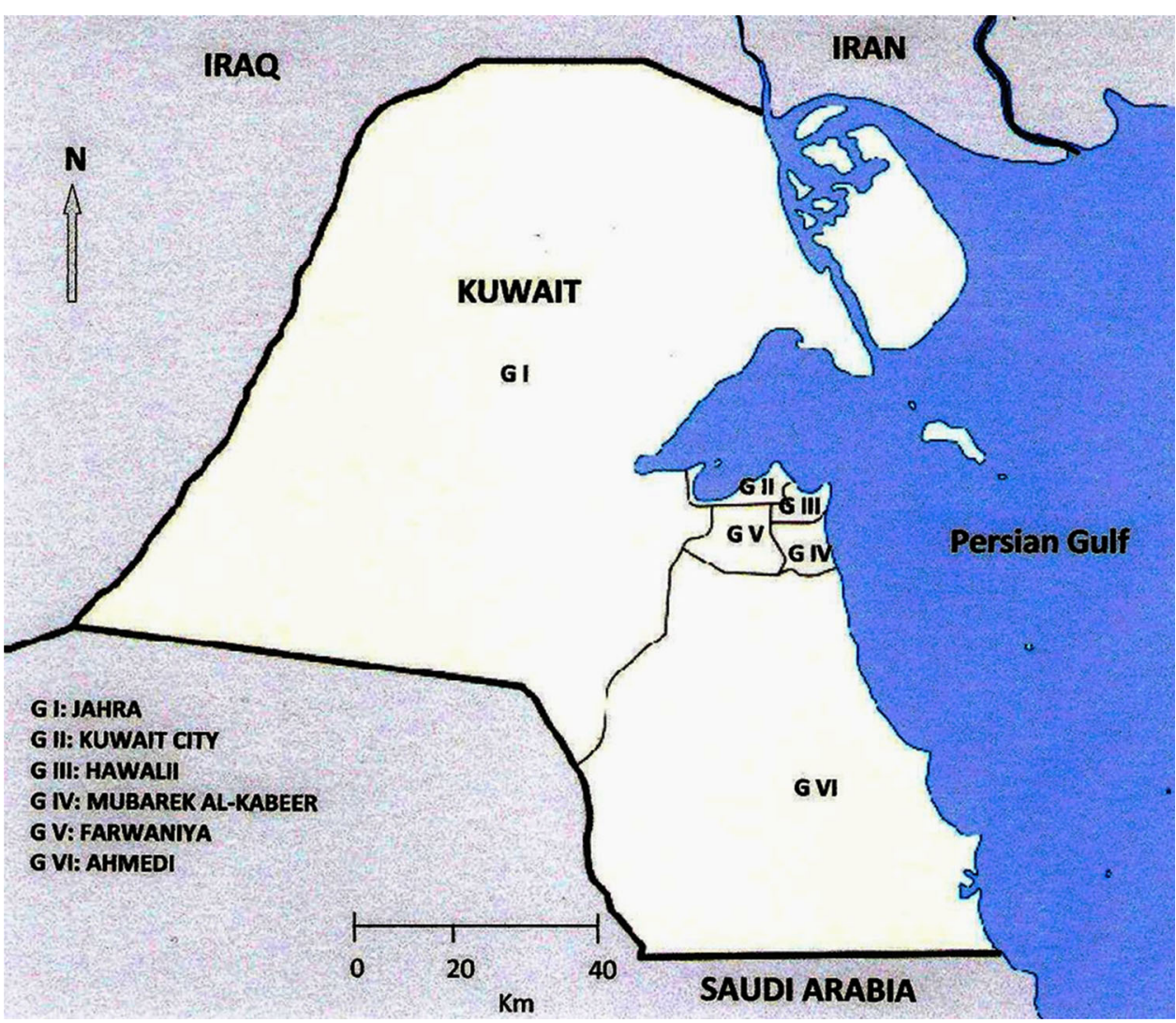

September) and winter (October-March) seasons. Meteorological data such as wind direction, wind speed, relative humidity, temperature, and dew point were recorded.

Sample collection

Desert plants (ten replicates $\times$ six species $\times$ four area$\mathrm{s} \times$ six Governorates $\times$ twice sampling in two seasons $=5,760$ Plants year $^{-1}$ ), such as Malva parviflora L., Fagonia bruguieri DC., Salsola imbricate Forssk., Tamarix chinensis Lour., Cornulaca aucheri Moq., and Tribulus terrestris L., were collected from six Kuwait Governorate areas during the years 2009-2011 (Fig. 1). Samples $(17,280)$ were thoroughly rinsed in deionized distilled water to remove the dust and soil. They were collected in sterile polyethylene labeled (Fischer brand, USA) zipper bags $(34 \mathrm{~cm} \times 30 \mathrm{~cm} \times 0.3 \mathrm{~mm})$, stored in Thermo Cole box, and transported to the laboratory. They were stored at $-4{ }^{\circ} \mathrm{C}$ before analysis. In sterilized Petri-dish $(9 \mathrm{~cm})$, the thawed plant parts (leaves, stem, and roots) were cut into small pieces $(5 \mathrm{~cm})$ using a sterile surgical blade (\#11), weighed $(0.2 \mathrm{~g})$, and analyzed for mercury in the direct mercury analyzer (DMA-80, Milestone, Italy).

Using a soil auger, $\left(15^{\prime \prime} \mathrm{L} \times 3-1 / 4^{\prime \prime}\right.$ diameter, AMS, Inc.), soil replicates $(50 \mathrm{~g})$ near the surrounding plants at $0.1 \mathrm{~m}$ depth were collected and stored in polyethylene container. Samples were oven dried (GallenKamp II, USA) at $45{ }^{\circ} \mathrm{C}$ until dryness. They were ground to obtain a homogenized powder and sieved using a $1 \mathrm{~mm}$ mesh, of which $0.2 \mathrm{~g}$ was analyzed for mercury concentrations (Keane et al. 2001).

Digestion of soil samples

Dried soil samples $(0.2 \mathrm{~g})$ collected from the surrounding plants were predigested with $4 \mathrm{ml} \mathrm{HNO}_{3}(\mathrm{v} / \mathrm{v}$, Aristar grade) overnight. $\mathrm{HNO}_{3}$ was further added to make up the volume to $5 \mathrm{ml}$ (recommended volume in the digester) and digested in a microwave digester (Ethos1, Milestone, Italy). This novel microwave digester edges over other conventional microwave digester in possessing a visually controlled monitoring feature with complete sample digestion ( $99 \pm 1 \%$ efficiency) in customized time, volume, and pressure validating perfection in technology. The digested soil samples were analyzed for $\mathrm{Hg}$ analysis in the DMA-80. Quality assurance using standard reference material (SRM-2709 San Joaquin Soil) from National Institute of Standard Technology (NIST, USA) through microwave digestion facilitated $100 \%$ recovery of $\mathrm{Hg}$ from the soil samples when compared to $98.4 \% \pm 0.3 \mathrm{Hg}$ recovery of undigested soil samples by direct analysis in the DMA- 80. 
Determination of mercury in desert plants and soil

The DMA-80 uses three principles, namely: (a) thermal decomposition to eliminate cumbersome sample preparation, handling and the use of hazardous chemicals, (b) catalyses to remove $\mathrm{N}_{2}, \mathrm{SO}_{2}$, halogen, and interfering compounds, and (c) amalgamation to trap $\mathrm{Hg}$ and release $\mathrm{Hg}$ through a carrier gas. The $\mathrm{Hg}$ flow is aligned to a tricell-positioned optical path spectrophotometer which measures $\mathrm{Hg}$ by atomic absorption at $253.65 \mathrm{~nm}$ wave length and compliant to EPA 7473 method. Thus, the three principles of DMA-80 in combination facilitate $\mathrm{Hg}$ analysis: (a) in elemental or gaseous forms, (b) in samples of solid, liquid and gaseous state at greater precision, (c) with low detection limits and standard error $\left(0.0015 \mathrm{ng} \mathrm{g}^{-1}\right.$ $1,000 \mu \mathrm{g} \mathrm{g}^{-1}$ and $\left.\pm 0.001 \mathrm{ng} \mathrm{g}^{-1}\right)$ compared with detection limits $\left(\geq 0.5 \mathrm{ng} \mathrm{g}^{-1}\right.$, ICP-MS $1-5 \mu \mathrm{g} \mathrm{g}^{-1}$ and $\pm 5 \mu \mathrm{g} \mathrm{g}^{-1}$ ) of other instruments such as HydraIIc, Ohiolumex (Dufault et al. 2009; Kolesnikov et al. 2010). In the present study, replicates (10 numbers) of the selected six species of plant parts (leaves, stem, and roots) and the digested soil samples $(0.2 \mathrm{~g})$ were analyzed in the DMA (DMA-80, Milestone, Italy). Quality assurance using standard reference material (SRM-1547 Peach leaves, NIST, USA) showed $99.99 \%$ recovery of plant samples and hence analyzed directly in the DMA-80 without microwave digestion. Analytical data were transformed to logarithmic concentrations to acquire precision results over wide-ranged samples.

Translocation (TF) and bioaccumulation factor (BF) of $\mathrm{Hg}$ in desert plants

Baker and Brooks (1989) revealed TF $>1$ in plants with effective translocation from root to the stem. Hg translocation in the desert plants from stem to root was measured using translocation factor (TF):

$\mathrm{TF}=\mathrm{Hg}$ concentrations in the stem $/ \mathrm{Hg}$ concentrations in roots

Ma et al. (2001) classified 'hyper-accumulators,' 'accumulator,' and 'excluders or bio-monitor' to those samples which accumulated metals $>10 \mu \mathrm{g} \mathrm{g}^{-1},>1$, and $<1$, respectively. Using this classification, $\mathrm{Hg}$ bioaccumulation factor (BF) in the desert plants was determined by calculating the ratio of $\mathrm{Hg}$ concentration in the aerial parts (stem and leaves) to that of the soil.

$\mathrm{BF}=C_{\mathrm{p}} / C_{\mathrm{s}}$

where $C_{\mathrm{p}}$ and $C_{\mathrm{s}}$ are $\mathrm{Hg}$ concentrations in aerial parts of the plant and in soil $\left(\mu \mathrm{g} \mathrm{g}^{-1}\right)$, respectively.

Quality control and assurance described by Keane et al. (2001) were carried out by using the $\mathrm{Hg}$ standards (ICP- grade), blanks, and SRM. Recovery of the samples to that of the standard reference material (SRM 2976) was $98.5 \%$, thus validating the precision of the instrument.

\section{Results and discussion}

Among the 370 desert plant species in Kuwait, in-depth studies were conducted on six desert plants, namely $M$. parviflora L., F. bruguieri DC., C. aucheri Moq., T. terrestris L., S. imbricate Forssk., and T. chinensis Lour., that were abundantly distributed in the six Kuwait Governorates and suspected for $\mathrm{Hg}$ absorption in their plant parts (leaves, stem, and root). The mean mercury ( $\mathrm{Hg}$ ) log concentrations in the desert plant parts ranged between 0.16 and $2.12 \mathrm{ng} \mathrm{g}^{-1}$ (Fig. 2). Among the six desert plants, $T$. chinensis Lour., revealed high $\mathrm{Hg}$ concentration that could be attributed to the absorption properties of the roots, foliage absorption from the ambient air besides, deducing the probable observations of Nahida et al. (2005), Prabha and Li (2007) and Zhuang et al. (2007) of high Hg exposure in shrub plants with more biomass (leaves) compared to the $\mathrm{Hg}$ levels in the plants with lower biomass.

$\mathrm{Hg}$ concentrations were high during summer than in winter irrespective of the different species. Frequent dust storms and wind direction causing $\mathrm{Hg}$ bound particulate deposition in desert plants during summer, $\mathrm{Hg}$ dissolution in soil from the chlor-alkali plant stationed near industrialresidential area, and evaporation of soil-bound mercury in warm periods could be related to the high $\mathrm{Hg}$ concentrations during summer than in winter. The above observation was in line with the findings of Liu et al. (2002), Al-Awadhi et al. (2008), and Lu et al. (2009). In addition to the above, earlier studies (Converse et al. 2010; Morales et al. 2011) showed that an increase in photosynthetic activity could probably elevate the absorption capabilities of the available $\mathrm{Hg}$ by plants during summer in contrast to activities of plants in winter.

Parts-wise analysis revealed high $\mathrm{Hg}$ concentrations in leaves $>$ roots $>$ stem in $T$. chinensis Lour., $>S$. imbricate Forssk., $>$ T. terrestris L., $>C$. aucheri Moq., $>M$. parviflora L., $>F$. bruguieri DC., respectively (Fig. 2). Reasons attribute to their absorption of gaseous or elemental $\mathrm{Hg}$ from ambient air or from soil through roots. The roots of these plants were reported to aid in translocation of $\mathrm{Hg}$ from soil to stem, and hence, $\mathrm{Hg}$ concentration was comparatively found higher than stem. This observation was in line with the findings of Rafia et al. (2006), Katnoria et al. (2008), Suruchi and Khanna (2011). In some plants, stem aids only in transport of $\mathrm{Hg}$ from roots to leaves, and hence, accumulation of $\mathrm{Hg}$ in stem is low. These observations were found supportive to that of the earlier studies (Al-Farraj and Al-Wabel 2007; Kadukova et al. 2008). 
Fig. 2 Plants parts-wise mercury levels (ng $\mathrm{g}^{-1} \log$. conc.) during summer and winter. $L v$ leaves, $S t$ stem, $R t$ root, $S$ summer, $W$ winter

Fig. 3 Governorates-wise mercury levels ( $\mathrm{ng} \mathrm{g}^{-1} \log$. conc.) in desert plants during winter. W: winter, GI-GVI Kuwait Governorates
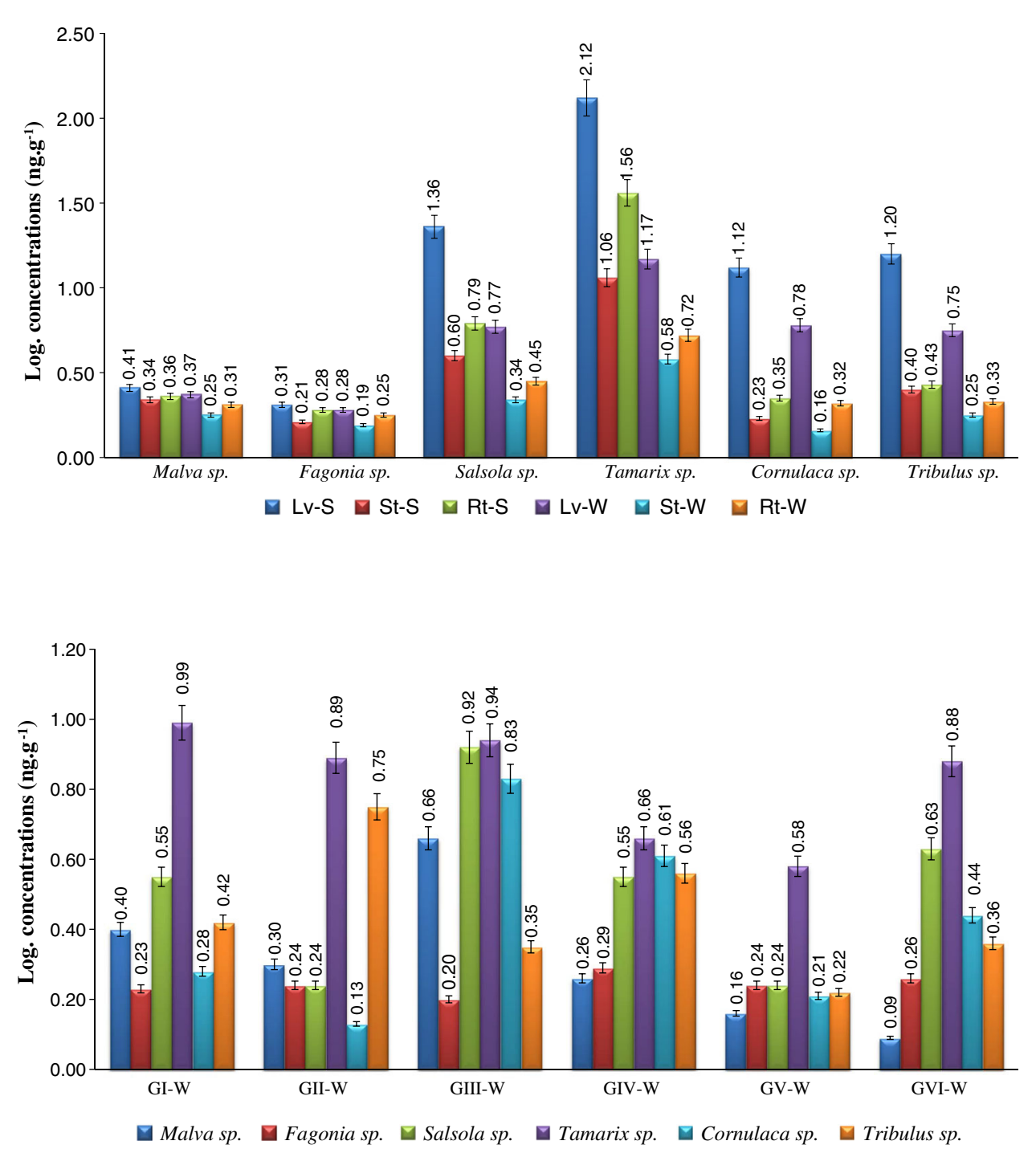

$\square$ Malva sp. $\square$ Fagonia sp. $\square$ Salsola sp. $\square$ Tamarix sp. $\square$ Cornulaca $s p . \square$ Tribulus $s p$.

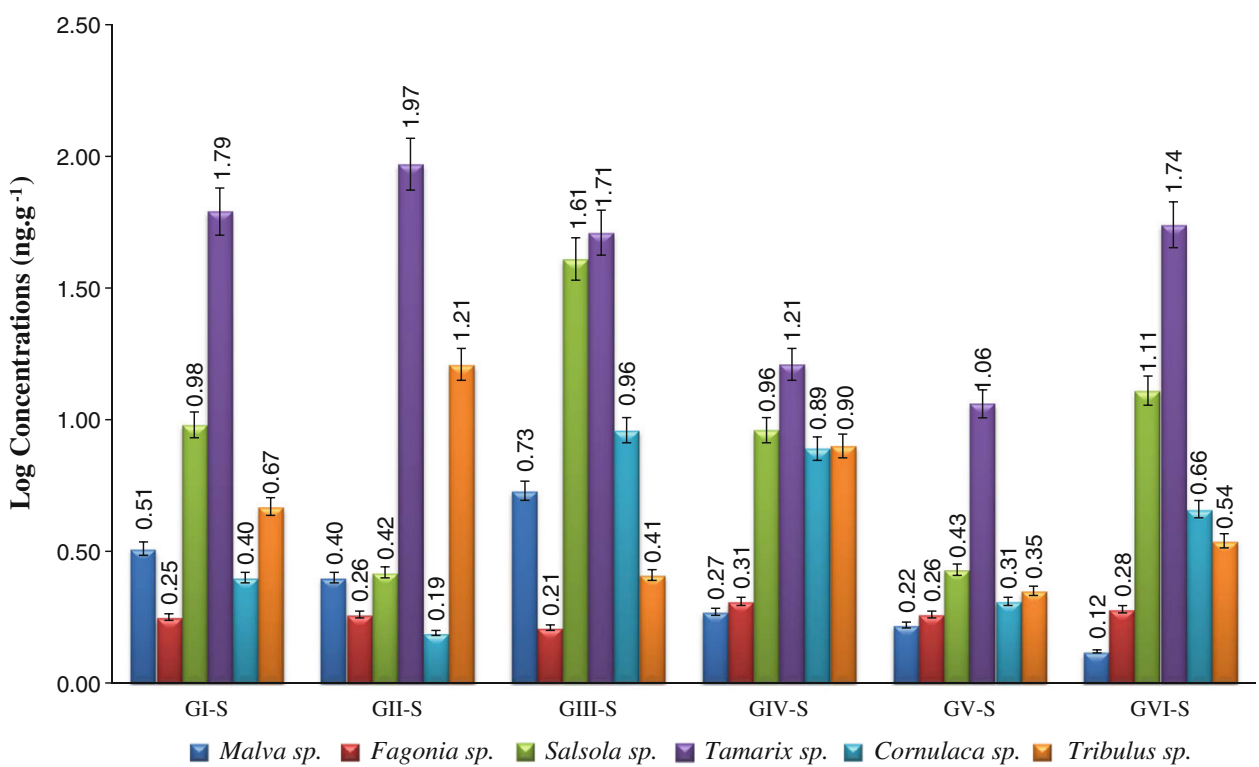

- Malva sp.
Fig. 4 Governorates-wise mercury levels (ng $\mathrm{g}^{-1} \log$. conc.) in desert plants during summer. $S$ summer, GI-GVI Kuwait Governorates 
Table 1 ANOVA on $\mathrm{Hg}$ concentrations in desert plants parts, Governorates, season-wise analyses, and surrounding soil

\begin{tabular}{|c|c|c|c|c|c|c|}
\hline Source of variation & SS & $d f$ & $F$ & $P$ value & $F$ ratio & Significance \\
\hline \multicolumn{7}{|c|}{ A. Desert plants species versus parts-wise $\mathrm{Hg}$ analysis } \\
\hline Plant species & 3.45 & 5 & 13.76 & 0.0016 & 2.60 & $*$ \\
\hline Parts (LSR) & 2.37 & 5 & 9.47 & 0.0036 & 2.60 & $*$ \\
\hline Error & 1.25 & 25 & & & & \\
\hline Total & 7.07 & 35 & & & & \\
\hline \multicolumn{7}{|c|}{ B. Governorate versus season-wise analysis } \\
\hline Governorates (GI-GVI) & 0.190 & 5 & 24.90 & 0.0015 & 5.05 & $*$ \\
\hline Seasons $(\mathrm{S}, \mathrm{W})$ & 0.210 & 1 & 139.46 & 0.0076 & 6.60 & $*$ \\
\hline Error & 0.007 & 5 & & & & \\
\hline Total & 0.407 & 11 & & & & \\
\hline \multicolumn{7}{|c|}{ C. Species versus Governorates-wise analysis } \\
\hline Plant species & 06.90 & 5 & 18.84 & 0.0072 & 2.38 & $*$ \\
\hline Governorates (GI-GVI) & 02.53 & 11 & 3.15 & 0.0023 & 1.96 & $*$ \\
\hline Error & 04.02 & 55 & & & & \\
\hline Total & 13.45 & 71 & & & & \\
\hline \multicolumn{7}{|c|}{ D. Soil analysis Governorate versus season-wise } \\
\hline Governorates (GI-GVI) & 0.025 & 5 & 205.48 & 0.008 & 5.05 & $*$ \\
\hline Seasons $(\mathrm{S}, \mathrm{W})$ & 0.003 & 1 & 126.75 & 0.0009 & 6.60 & * \\
\hline Error & 0.001 & 5 & & & & \\
\hline Total & 0.029 & 11 & & & & \\
\hline \multicolumn{7}{|c|}{ E. Desert plant parts (leaves, stem, root) versus soil } \\
\hline Species & 1.33 & 5 & 5.55 & 0.004 & 2.90 & $*$ \\
\hline Parts (LSR) and soil & 13.04 & 3 & 90.69 & $7.69 \times 10^{-10}$ & 3.29 & * \\
\hline Error & 0.72 & & & & & \\
\hline Total & 15.09 & & & & & \\
\hline
\end{tabular}

LSR leaves, stem roots; GI-GVI Kuwait Governorates; $S, W$ summer, winter; $S S$ sum of squares; $d f$ degree of freedom; $F$ calculated value; $F$ ratio table value

* Significant

Fig. 5 Governorates-wise mercury levels ( $\mathrm{ng} \mathrm{g}^{-1} \log$. conc.) in soil surrounding the desert plants. $S$ summer, $W$ winter, GI-GVI Kuwait Governorates

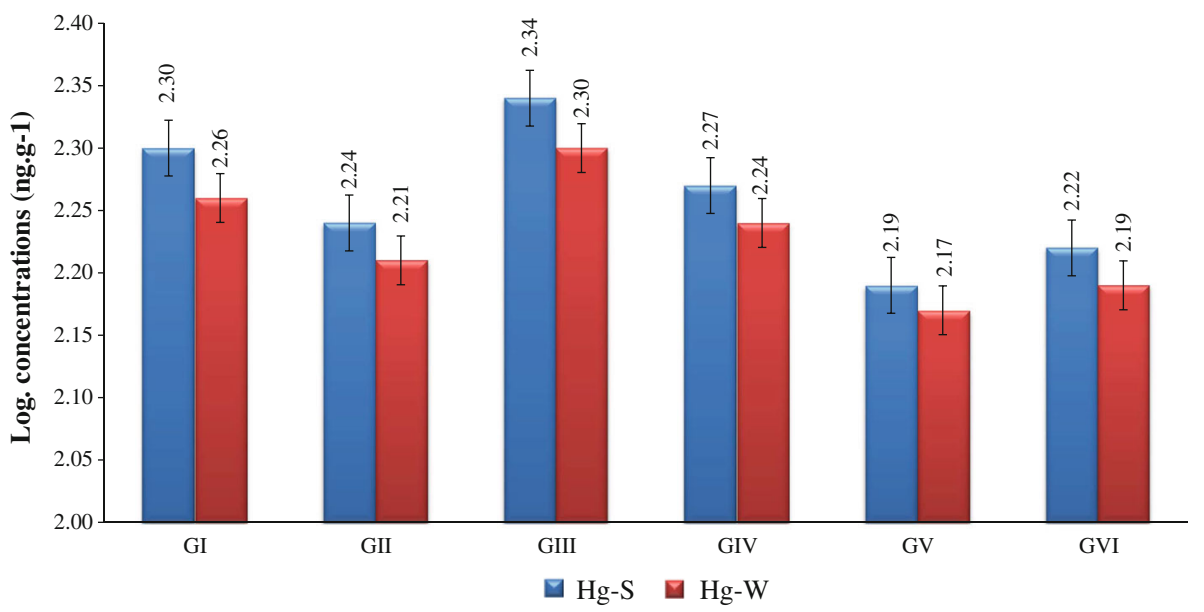

The overall Governorate wise analysis on these desert plants showed high $\mathrm{Hg}$ concentrations sequence of GIII $>$ GI $>$ GIV $>$ GII $>$ GVI $>$ GV during summer and winter seasons of Kuwait (Figs. 3, 4). Industrial wastewater percolation in the soil from chlor-alkali plants, domestic wastewater discharges, and influence of $\mathrm{Hg}$ vapor in the ambient air released from anthropogenic activities attribute to the high $\mathrm{Hg}$ concentration in GIII and GI. This supports the views of Charron and Harrison (2003), Rafat et al. (2009). Governorate wise analysis showed comparatively higher $\mathrm{Hg}$ concentrations in T. chinensis Lour., in GII and GIII because of this plant's inorganic and organic bound 
Fig. 6 Seasonal-wise translocation and bioaccumulation factors $\left(\mathrm{ng} \mathrm{g}^{-1}\right.$ log. conc.) for desert plants in Kuwait. $T F$ translocation factor, $B F$ bioaccumulation factor, $S$ summer, $W$ winter

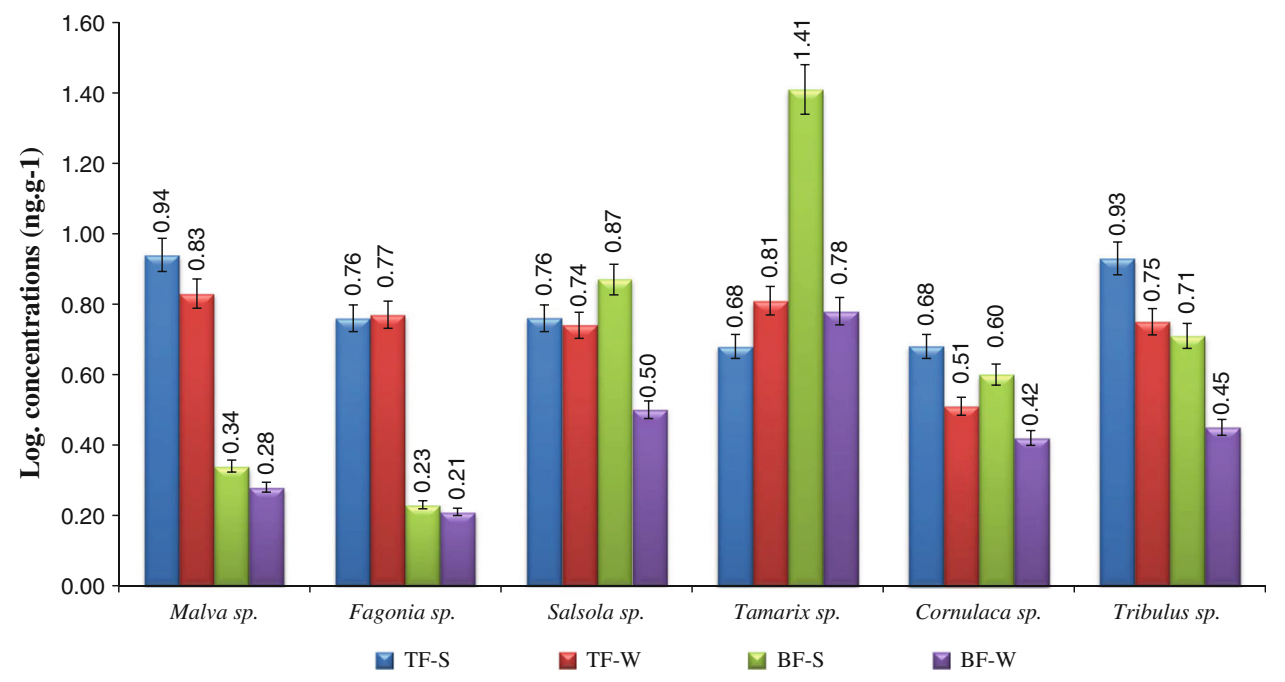

soil $\mathrm{Hg}$ absorbing capabilities of their roots, foliage susceptibility to $\mathrm{Hg}$ vapor from the ambient air in addition to their abundant apportionment of plants in this Governorate compared to its distribution elsewhere the other Governorates. Statistical tests by ANOVA showed significant differences among $\mathrm{Hg}$ concentrations in the six desert plants during both seasons (summer and winter) and in the respective Kuwait Governorate areas (Table 1A-C).

Comparatively, $\mathrm{Hg}$ concentration was high in soil collected from different Governorate areas when compared to the $\mathrm{Hg}$ concentrations in the desert plants. $\mathrm{Hg}$ concentrations sequence in soil samples revealed similar Governorate wise sequence to that of the desert plants (Fig. 5). Eolian dust deposition, frequent sandstorms, and industrial activities that discharge wastes into the soil without proper treatment attributes to the high $\mathrm{Hg}$ levels in the soil samples. Such observations were found in line with the earlier studies of Freer-Smith et al. (2004), Chung et al. (2005), Onweremadu et al. (2007), Rafat et al. (2009), USEPA (2009), and Morales et al. (2011). ANOVA showed significant differences between $\mathrm{Hg}$ concentrations in the soil during the two seasons and in the respective Kuwait Governorate areas (Table 1D). Statistical test by ANOVA revealed significance between the exposure of $\mathrm{Hg}$ from soil to the different parts of each desert plants (Table 1E).

It is interesting to note that translocation and bioaccumulation factors were low $(\mathrm{TF}<1)$ in most of the sampled desert plants, probably indicating seldom or low absorption of $\mathrm{Hg}$ from roots to the other aerial plant parts (Fig. 6). However, BF in desert plants and soil was found lower than the permissible limits $\left(0.5 \mathrm{mg} \mathrm{l}^{-1}\right)$ of CEPA (2009) and USGS (2009). This observation agreed with the earlier findings of Baker and Brooks (1989), Ma et al. (2001), and Takashi et al. (2005) labeling plants with $\mathrm{TF}<1$ as bioindicators of pollution and $\mathrm{TF}>1$ as 'hyper' and 'accumulators' of pollution. BF was $>1$ in the case of T. chinensis Lour., especially during summer. Reasons may attribute to the following: (a) the $\mathrm{Hg}$ exposure from ambient air to the larger biomass of this plant in comparison with the other smaller sampled desert plants, as a result of frequent dust storms in Kuwait, (b) its halophytic nature, (c) the nature of roots that absorbs $\mathrm{Hg}$ from the surrounding soil to a certain extent which is present in organic speciation (sulfates, chlorides) and, (d) the $\mathrm{Hg}$ absorption from the surrounding soil containing $\mathrm{Hg}$ accumulated fallen $T$. chinensis Lour., leaves.

\section{Conclusion}

The present study revealed the state-of-the-art-technology in determining $\mathrm{Hg}$ concentrations in plants and soil samples at ultra-trace-level precision $\left(0.0015 \mathrm{ng} \mathrm{g}^{-1}\right.$ detection limits), rapidly and with seldom contamination using the DMA-80 unlike other instruments that has $\geq 0.5 \mathrm{ng} \mathrm{g}^{-1}$ detection limits. In an overall view, $\mathrm{Hg}$ concentrations in plants and soil samples were lower than the statutory permissible limits. Analysis on these desert plant parts revealed partial or slow process of $\mathrm{Hg}$ translocation and bioaccumulation compared with earlier studies in other trace metals in foliar plants. However, the recent trend in urbanization and construction activities with increasing population in Kuwait is anticipated to increase the $\mathrm{Hg}$ concentrations in the near future. The present study reveals that desert plants, such as $T$. chinensis Lour., and $S$. imbricate Forssk., could be characterized as a tool for biomonitoring studies. Further, taxonomical studies could be undertaken to label some of these desert plants for possible phytoremediation and curb $\mathrm{Hg}$ pollution in countries with arid ecosystem. 
Acknowledgments We thank the Kuwait Foundation for the Advancement of Sciences (KFAS) and Research Administration, Kuwait University for their invaluable financial and technical support to our project (KFAS-2006-1401-02). We also wish to thank Dr. K.T. Mathews, Curator, Herbarium unit, Dept. of Biological Sciences for identifying the desert plant species.

\section{References}

Al-Awadhi L, Khan AR, Al-Kandari R (2008) Trace metal mercury in residential homes in Kuwait. Am J Environ Sci 4(1):77-83. doi: 10.3844/ajessp.2008.77.83

Al-Farraj AS, Al-Wabel MI (2007) Heavy metals accumulation of some plant species grown on mining area at Mahad AD'Dahab, Saudi Arabia. J Appl Sci 7(8):1170-1175. doi:10.3923/jas.2007. 1170.1175

Arab Times (2011) Tsunami of sand tortures Kuwait, dark before sunset at $50 \mathrm{~km}$ per hour. http://www.arabtimesonline.com/ NewsDetails/tabid/96/smid/414/ArticleID/167172/t/Tsunami-ofsand-tortures-Kuwait/Default.aspx. Accessed 2 Dec 2011

Baker AJM, Brooks RR (1989) Terrestrial higher plants which hyper accumulate metallic elements-a review of their distribution, ecology and phytochemistry. Biorecovery 1:81-126

CEPA (2009) Ambient air quality standards for particulate matter. http://www.arb.ca.gov/research/aaqs/pm/pm.htm. Accessed 5 Nov 2011

Charron A, Harrison RM (2003) Primary particle formation from vehicle emissions during exhaust dilution in the roadside atmosphere. Atmos Environ 37(29):4109-4119. doi:10.1016/ s1352-2310(03)00510-7

Chung YS, Kim SH, Moon JH, Kim YJ, Lim JM, Lee JH (2005) Source identification and long term monitoring of airborne particulate matter (PM 2.5/PM 10) in an urban region of Korea. J Radio Anal Nucl Chem 267(1):35-48. doi:10.1007/s10967006-0006-Z

Converse AD, Riscassi AL, Scanlon TM (2010) Seasonal variability in gaseous mercury fluxes measured in a high-elevation meadow. Atmos Environ 44:2176-2185. doi:10.1016/j.atmosenv.2010.03.024

Dufault R, LeBlanc B, Schnoll R, Cornett C, Schweitzer L, Wallinga D, Hightower J, Patrick L, Lukiw WJ (2009) Mercury from chlor-alkali plants: measured concentrations in food product sugar. Environ Health 8:2. doi:10.1186/1476-069X-8-2

Eboh LO, Thomas BE (2005) Analysis of heavy metal content in cannabis leaf and seed cultivated in southern part of Nigeria. Pak J Nutr 4(5):349-351. doi:10.3923/pjn.2005.349.351

Freer-Smith PH, El-Khatib AA, Taylor G (2004) Capture of particulate pollution by trees: a comparison of species typical of semi-arid areas (Ficus nitida and Eucalyptus globules) with European and North American Species. Water Air Soil Pollut 155:173-187. doi:10.1023/B:WATE.0000026521.99552.fd

Greenwell M (2008) Kuwait's unique plants 'on the verge of extinction'. Exit stage right extinction news service. http:// exitstageright.wordpress.com/2008/03/06/Kuwaits-uniqueplants-on-the-verge-of-extinction. Accessed 5 Nov 2011

Kadukova J, Manousaki E, Kalogerakis N (2008) $\mathrm{Pb}$ and $\mathrm{Cd}$ accumulation and phyto-excretion by salt Cedar (Tamarix smyrnensis Bunge). Int J Phytoremed 10(1):31-46. PMID 18709930

Katnoria JK, Arora S, Nagpal A (2008) Genotoxic potential of agricultural soils of Amritsar. Asian J Sci Res 1(2):122-129. doi: 10.3923/ajsr.2008.122.129

Keane B, Collier MH, Shann JR, Rogstad SH (2001) Metal content of dandelion (Taraxacum officinale) leaves in relation to soil contamination and airborne particulate matter. Sci Total Environ 281:63-78. doi:10.1016/s0048-9697(01)00836-1

Kolesnikov SP, Rubinskaya TY, Strel'tsova ED, Leonova MYu, Korshevets IK, Zykov AM, Anichkov SN (2010) Distribution of mercury in the combustion products of coal dust in boilers with liquid slag removal. Solid Fuel Chem 44(1):50-55. doi: $10.3103 / \mathrm{SO} 361521910010106$

KUNA (Kuwait News Agency) (2010) Astronomer Al-Saadoun finds rare plants at Sabah Al-Ahamed natural reserve, IIK, posted 26th May, 2010. http://www.Indiansinkuwait.com/ShowArticle.aspx? ID $=5543 \&$ SECTION=0\#ixzz1jVeelv3S. Accessed 8 Jan 2011

Ling T, Fangke Y, Jun R (2010) Effect of mercury to seed germination, coleoptiles growth and root elongation of four vegetables. Res J Phytochem 4(4):225-233. doi:10.3923/rjphyto. 2010.225.233

Liu S, Nadim F, Perkins C, Carley RJ, Hoag GE, Lin Y, Chen L (2002) Atmospheric mercury monitoring survey in Beijing, China. Chemosphere 48(1):97-107

Lu XW, Li LY, Wang LJ, Lei K, Huang J, Zhai YX (2009) Contamination assessment of mercury and arsenic in roadway dust from Baoji, China. Atmos Environ 43(15):2489-2496. doi: 10.1016/j.atmosenv.2009.01.048

Ma LQ, Komar KM, Tu C, Zhang W, Cai Y, Kenelly ED (2001) A fern that hyper accumulates arsenic. Nature 409:579-582

Morales JG, Ofelia MB, Elizabeth HA, Maria TRS, María EGA, Víctor TC (2011) Assessment of atmospheric metal pollution in the urban area of Mexico City, using Ficus benjamina as biomonitor. Bull Environ Contam Toxicol 86(5):495-500. doi: 10.1007/s00128-011-0252-9

Nahida B, Al-Majed BT, Preston MR (2005) Atmospheric vapour phase and particulate phase mercury in a coastal desert climate. J Environ Monit 7:977-982. doi:10.1039/b506386h

Onweremadu EU, Asawalam DO, Ibe AE (2007) Changes in soil properties following application of composted sludge on an isohyperthermic Kandiudult. Res J Environ Technol 1(2):62-70. doi:10.3923/rjet.2007.62.70

Prabha KP, Li LY (2007) Phytoremediation technology: hyperaccumulation metals in plants. Water Air Soil Pollut 184(1-4):105-126. doi:10.1007/s11270-007-9401-5

Rafat MN, El-Ashgar NM, Mahmoud MI, Al-Slieby M (2009) Detection of some heavy metals due to sewage water diffusion into planted land. J Environ Sci Technol 2(2):88-94. doi: 10.3923/jest.2009.88.94

Rafia A, Askari S, Haider S (2006) Effect of toxic metal mercury on histomorphology of Cyamopsis tetragonoloba. Asian J Cell Biol 1(1):34-39

Suruchi S, Khanna P (2011) Assessment of heavy metal contamination in different vegetables grown in and around urban areas. Res J Environ Toxicol 5:162-179. doi:10.3923/rjet.2011.162.179

Takashi T, Tomonori M, Junko M, Ryusuke I, Katsuro A, Hayao S (2005) Low level mercury uptake by plants from natural environments-mercury distribution in Solidago altissima L. Environ Sci 12(4):231-238 [cross referred ISSN 0915-955X]

USEPA (2009) National ambient air quality standards. http:// www.epa.gov/air/criteria.html. Accessed 8 Aug 2011

USGS (2009) Mercury in the environment. Fact sheet 146-00, pp 1-8. http://www.usgs.gov/themes/factsheet/146-00/index.html. Acce ssed 11 Nov 2011

Windfinder (2011) Wind and weather statistic in Kuwait based on observations taken between 9/2006-3/2011 daily from 7 am to $7 \mathrm{pm}$ local time. http://www.windfinder.com/windstats/windst atistickuwait_city.htm. Accessed 5 Nov 2011

Zhuang P, Yang QW, Wang HB, Shu WS (2007) Phytoextraction of heavy metals by eight plant species in the field. Water Air Soil Pollut 184:235-242. doi:10.1007/s11270-007-9412-2 